\title{
The Refusal of Minting Ottoman Silver Para Multiples in Egypt as a Reflection of the Political Relation with the Ottoman Sultanate
}

Dr. Eman Mahmoud Arafa

\begin{abstract}
:
During the Ottoman reign in Egypt (918-1222 A.H/15201807A.D), while the mint of Istanbul -the capital of the Ottoman Sultanate- was responsible for minting the multiples of the Para, Egypt refused to follow this coinage tradition, despite the fact that it was a state of the Ottoman Empire. This practice on behalf of Egypt reflects some important political events that may show the concealed reaction of refusal and opposition to the Ottoman reign in being against minting through the silver coins as a secondary coin, and not through the golden coins which were the essential ones. In addition, it reflects the power of the Emirs in Egypt during some periods of the Ottoman era. In fact, the only time Egyptian authority has departed this reaction of refusal, was during the reign of Sultan Mustafa the third when Ali Beik alKabir struck Para multiples holding his name, although the intention here was to make it as an act of confrontation to the Ottoman reign. Thus, this analytical study aims at introducing a new perspective of study by examining the coins in a method that reveals the political relations during that era, along with publishing some examples for the coins.
\end{abstract}

\section{Keywords:}

Ottoman Era, Para Multiples, Minting, Political Relations, Medin

\footnotetext{
- Faculty of Archeology, Cairo University, Cairo, Egypt, iman.arafa14@gmail.com
} 


\section{Introduction:}

The reign of Sultan Selim the First, (918-926A.H. / 1512-1520 A.D.), represents a turning point in Egypt's history, as he is the one who turned Egypt from a Mamluk Sultanate to a State of the Ottoman Empire.

In 923 A.H. / 1517 A.D. Sultan Selim the First conquered Egypt ${ }^{1}$. Under his leadership, he eliminated all Mamluk resistance, occupied Egypt, and established his own government in Cairo ${ }^{2}$. Egypt then was administrated as an Eyalet "state" of the Ottoman Empire, which has always been a difficult province for the Ottoman Sultans to control, due to the continuing power and influence of the Mamluks.

Thus, Egypt remained semi-autonomous under the Mamluk rule until it was invaded by the French forces of Napoleon in 1213 A.H. / 1798 A.D. during the reign of the $28^{\text {th }}$ Sultan, "Sultan Selim the Third" (1203-1222 A.H. /1789-1801 A.D.). This French expedition, which invaded Egypt, helped Muhammad Ali Pasha-an Albanian military commander of the Ottoman Army in Egypt- to seize the power in 1815 A.D.

In light of such political events, one would expect that the Ottomans would have done their best in conquering Egypt to totally destroy the Mamluks, and to control the country more closely. Surprisingly, they seem to have made no real effort to gain power, for the Mamluk's system survived and continued, and in time they even increased their power. In fact, it is logical

${ }^{1}$ Suleiman, A. A. (1972). History of the Islamic countries and the lexicon of the ruling dynasties, Part 2, Egypt: Dar al-Maaref, p. 443.

${ }^{2}$ Pipes, D. (1983). Mamluk survival in Ottoman Egypt. Journal of Turkish Studies, p. 1.

${ }^{3}$ Arafa, E. M. (2006). The Coins which were used in Egypt during the French Expedition. (M.A. Thesis). Cairo University: Faculty of Archeology, Egypt, p. 12. 
to surmise that they would have broken away from the Ottoman control had Napoleon not invaded Egypt in 1213 A.H. / 1798 A.D. ${ }^{4}$.

Accordingly, the events of the early Ottoman Egypt reflect the struggle over power between the Mamluks and the representatives of the Ottoman Sultan. Besides, after the conquest of Egypt, the Ottoman Sultan Selim the First left the country, and Hayir Bey was awarded the governorship of Egypt; the former Mamluk Governor in Aleppo 5 .

The Ottoman conquest meant that the ruler of Egypt would pay rather than receive tribune; before 922 A.H. / 1513 A.D., Egypt received tribune from Syria, Cyprus, parts of Sudan and many other provinces, but under the current situation Hayir Bey had to send periodic gifts in cash and coins to Sultan Selim from his own revenues 6 .

In addition, after Egypt had been a major country, it turned to be an Ottoman State, since the year 923 A.H. /1514A.D., and coins minting became to be determined by the Ottoman Sultan's orders which were sent directly from Istanbul ${ }^{7}$. So, the two Islamic prerogatives of sovereignty (mention of the ruler's name in weekly prayers in mosques in the Friday sermons and the coinage) now belonged to Sultan Selim ${ }^{8}$. Especially that minting coins under the name of the ruler was considered as an act that is confined to Sultan's only to represent authority, and accordingly

\footnotetext{
${ }^{4}$ Pipes, D. (1983). Mamluk survival in Ottoman Egypt. Journal of Turkish Studies, p. 1.

${ }^{5}$ Pitcher, D. E. (1972). A historical geography of the Ottoman Empire from earliest times to the end of the $16^{\text {th }}$ century. Brill Archive, p. 105.

${ }^{6}$ Shaw, S. J. (1962). The financial and administrative organization and development of Ottoman Egypt: 1517-1798. Princeton, p. 283.

${ }^{7}$ Al Sawy, A. A. (2001). The coins which were used in Ottoman Egypt.

First edition, Cairo: Arab Civilization Center, p.12.

${ }^{8}$ Pipes, D. (1983). Mamluk survival in Ottoman Egypt. Journal of Turkish Studies, p. 3.
} 
each Sultan was keen on taking this action once he holds the throne ${ }^{9}$.

The importance of coins was not limited to only being the sign of rule, but in fact, its political value was much more profound as it played a huge role in shedding more light on the different historical events and states. Certainly, besides its normal role as representing the essence and core of the economic state, it is also considered the main reflection of $i^{10}$. For example, fraud and forgery of coins at any time reflect the regressive economic state, for this forgery comes by cutting parts of the margin of the coin, so as to decrease its weight ${ }^{11}$. Egypt had witnessed this phenomenon during the Ottoman Era as in 1104 A.H. / 1692 A.D., when the cut silver coins had spread ${ }^{12}$. Also, through the study of the mints, the geographical boundaries for any country and its territories can be determined ${ }^{13}$. Thus, their function is not only confined to a representation of economy.

Concerning the political role of coins -subject of study- firstly, it is important to mention that the Ottoman Sultanate gave the attention to minting gold and silver coins, and as the territories of the Ottoman Empire were spreading through vast areas, minting

${ }^{9}$ El Nabarawy, R. (2000). The Islamic coins from the beginning of the $6^{\text {th }}$ century till the end of the $9^{\text {th }}$ century A.H. First edition, Cairo: Zahraa alSharq Library, p.5.

${ }^{10}$ El Nabarawy, R. (2000). The Islamic coins from the beginning of the $6^{\text {th }}$ century till the end of the $9^{\text {th }}$ century A.H. First edition, Cairo: Zahraa alSharq Library, p. 16.

${ }^{11}$ Mansour, A. R. (2008). The Islamic coins and their importance in studying history, archeology, and civilization. First edition, Cairo: Zahraa al-Sharq, p. 20.

${ }^{12}$ Mubarak, A .B. (1883). New plans for Egypt and its old and famous states. Part 20, Cairo: Beau Lac Printing House, p.149.

${ }^{13}$ Mansour, A. R. (2008). The Islamic coins and their importance in studying history, archeology, and civilization. First edition, Cairo: Zahraa al-Sharq, p.20. 
coins was not limited to the borders of the Capital ${ }^{14}$. But, simultaneously, it was notable that there has been a unified prototype for all Ottoman coins struck in the different Ottoman countries, based on the decree which was sent whenever a new Sultan takes the throne ${ }^{15}$.

In accordance, Egypt, being one of the Ottoman States, was obliged to follow a specific prototype and tradition in its monitory system. In this regard, throughout the Ottoman Era, Egypt has abided by the trend of the Ottoman Empire in minting the gold coins, but this same era has sometimes witnessed several contraventions to this Sultanate's orders, concerning the minting of the silver coins, especially that the Ottoman Sultans used to give more attention for the minting of gold coins and not the silver ones. This is due $t$ the fact that most of the official decrees of the Ottoman Sultans were sent with details concerning the weight, prototype, and the caliber of the gold coins only, besides the minting templates ${ }^{16}$.

For example, the decree of the year 1109 A.H. / 1697 A.D., was sent with the details of the gold coins only, along with its minting templates ${ }^{17}$, without any information concerning the silver coins, for the content of the decree text stated the caliber of the gold

${ }^{14}$ Oghlu, A. A. (1999). The Ottoman state, history, and civilization.

Translated by Saleh Saadawy. Part 2. Istanbul: Islamic History, Arts, and Culture Center, p. 669.

${ }^{15}$ Al Sawy, A. A. (2001). The coins which were used in Ottoman Egypt. First edition, Cairo: Arab Civilization Center, p. 20.

${ }^{16}$ Al Sawy, A. A. (2001). The coins which were used in Ottoman Egypt. First edition, Cairo: Arab Civilization Center, p. 227.

${ }^{17}$ Al Jabarti, A. A. (2003). Ajae'b al-athaar fe al-tarajem wa al-akhbar. Edited by Abdel Reheem Abdel Rahman. Cairo: The General Egyptian Book Organization, p. 40. 
coins to be 22 carats and the weight of every 100 Dinar that equate 150 Egyptian Dirhams ${ }^{18}$.

This procedure certainly provided an opportunity to violate the Ottoman trend of minting silver coins, and even more than that, resistance was reflected in refusing some direct decrease of minting specific coins of it, as it is going to be mentioned.

Resistance was seen in that at the time when in Constantinople, silver coins of fixed amounts of $(100,80,60,40,20$, and 10 Paras), as well as five Paras were minted, Egypt did not follow this series of silver coins as commonly known, depending on arithmetic progression in which the Para was recorded to be at its least standards ${ }^{19}$.

Another highly significant fact was that the Turks in general and Egyptians in specific struck few silver coins, which in turn limited the use of silver coins in major trade transactions in Egypt to foreign $\operatorname{coins}^{20}$. Not only that, but also no Ottoman coins have been found prior to the $13^{\text {th }}$ century A.H. / the $19^{\text {th }}$ A.D. representing it $^{21}$.

The silver monitory system of the Ottoman Era started with the "AKCE" (Figure 1), which was considered as the smallest monitory unit before the Para came to replace it, which was an Egyptian Turkish coin having different prices in different years,

\footnotetext{
${ }^{18}$ Mubarak, A .B. (1883). New plans for Egypt and its old and famous states. Part 20, Cairo: Beau Lac Printing House, p.201.

${ }^{19}$ Bernard, S. (2002). Description of Egypt. Part 6. Translated by Zuheir alShayeb. Cairo: The General Egyptian Book Organization, p. 74.

${ }^{20}$ Raymond, A. (1999). Artisans et commercants au Caire. Le Caire: Institut Francias d'Archeologie Orientale, p. 20.

${ }^{21}$ Gibb, H. (1989). Islamic society and the West. Cairo, p. 114.
} 
and measured by the halves ${ }^{22}$, and in time it became the main value of the silver coin in Egypt and in Istanbul as well ${ }^{23}$.

When the Ottomans conquered Egypt, they kept the small value silver coins known as the half silver (Figure 2), later became to be named the Para (Figure 3). It remained to represent the main silver coin in Egypt till the end of the $12^{\text {th }}$ century A.H. / the $18^{\text {th }}$ A.D. ${ }^{24}$.

Thus, the half silver and Para were two names referring to the same coin ${ }^{25}$. Yet, the date in which this coin has been struck outside Egypt for the first time remained unknown, although it was asserted that Para became commonly synonymous to the half silver in Egypt since the age of Suleiman al-Qanouni ${ }^{26}$.

Besides the half silver and Para names, the naming (Medin) or (Medi) appeared in reference to King Al-Moaed Abu El-Nasr Sheikh (815-824 A.H. / 1412-1420 A.D.), for he struck half Dirham named after him. The oldest confirmed statement of this coin was in a waqf document of a university listing the imam salaries that were given in half silver coins ${ }^{27}$.

${ }^{22}$ Amer, M. A. (1997). Coins, weights, and measures. Damascus: Ibn Khaldoun Publishing, p. 185.

${ }^{23}$ Al Sawy, A. A. (2001). The coins which were used in Ottoman Egypt. First edition, Cairo: Arab Civilization Center, p. 84.

${ }^{24}$ Inalik, H. (1994). Money in the Ottoman Empire: an economic and social history of Ottoman Empire. Cambridge University Press, p.957.

${ }^{25}$ Raymond, A. (1999). Artisans et commercants au Caire. Le Caire: Institut Francias d'Archeologie Orientale, p. 26.

${ }^{26}$ Al Sawy, A. A. (2001). The coins which were used in Ottoman Egypt.

First edition, Cairo: Arab Civilization Center, p. 85.

${ }^{27}$ Al Sawy, A. A. (2001). The coins which were used in Ottoman Egypt. First edition, Cairo: Arab Civilization Center, p. 84. 
This name was common among the French expedition scientists $^{28}$, and it was also used by Andree Raymond when he stated that the Para was an originally Egyptian Mamluk coin known as Al- Moaedi, which is half dirham having several names, like Medi, Medin, and half silver ${ }^{29}$.

As previously mentioned, Constantinople followed the arithmetic progression divisions in the struck of the silver coins of fixed amounts and prices, the least of which were the Para ${ }^{30}$. Accordingly, various multiples were struck from the Ottoman Para $^{31}$.

These multiples began with the Beslik, a Turkish silver coin, the name of which consisted of (bes), a simplification of the Persian word (Bis) meaning five, and (lik), which is a tool that proceeds numbers in Turkish language to refer to the units included. Thus, Beslik means a coin of five Para ${ }^{32}$. Besides, there is the 10 Para piece, known as Onlik (Figure 4$)^{33}$. Moreover, the Nibeslik appeared for the 15 Para coin, entitled half Saldi by the Egyptians $^{34}$. As for the 20 Para pieces, they were known as the Yakramlik $^{35}$.

${ }^{28}$ Bernard, S. (2002). Description of Egypt. Part 6. Translated by Zuheir alShayeb. Cairo: The General Egyptian Book Organization, p. 71.

${ }^{29}$ Raymond, A. (1999). Artisans et commercants au Caire. Le Caire: Institut Francias d'Archeologie Orientale, p. 33.

${ }^{30}$ Bernard, S. (2002). Description of Egypt. Part 6. Translated by Zuheir alShayeb. Cairo: The General Egyptian Book Organization, p.74.

${ }^{31}$ Al Sawy, A. A. (2001). The coins which were used in Ottoman Egypt.

First edition, Cairo: Arab Civilization Center, p. 85.

${ }^{32}$ Fahmy, A. (1976). The coins used during the time of Al-Jabarti. Cairo: The General Egyptian Book Organization, p. 572.

${ }^{33}$ Al Sawy, A. A. (2001). The coins which were used in Ottoman Egypt. First edition, Cairo: Arab Civilization Center, p. 85.

${ }^{34}$ Al Sawy, A. A. (2001). The coins which were used in Ottoman Egypt. First edition, Cairo: Arab Civilization Center, p. 86.

${ }^{35}$ Mahmoud, A. M. (2003). Ottoman coins: Their history and problems. Cairo: Faculty of Arts Library, p. 107. 
Zolota (Figure 5) was the coin struck with an amount of 30 Para $^{36}$. It was known among the Egyptians as the Saldi ${ }^{37}$. As for Akluk, it represents the fifty Para ${ }^{38}$. There was also Tamselik, which is a Turkish word derived from sixty along with the average unit, thus meaning sixty $\operatorname{Para}^{39}$ (Al Karamali, 1987).

Finally, there was the hundred Para amount, known as Yuzlik (Figure 6) ${ }^{40}$. In fact, Yuzlik was the biggest amount in Ottoman coins, and the most common, and it reveals the deterioration of the age of coins classification from best to worst. Although the Para and Yuzlik were conveniently reachable coins, the other ones were difficult to obtain, as the Beslik, and 20 Para were very few, while the most difficult to find was Zolota ${ }^{41}$.

It is worth mentioning that these coins were delivered to Egypt among other types of ottoman coins and were used by Egyptians in transactions, but they did not constitute a major part of the locally exchanged silver coins, in addition to that they were not struck in Egypt. However, this does not connote their refusal, as there is no relation between not being struck in Egypt and the refusal to accept them in trading transactions of buying and selling $^{42}$. Consequently, it is clear that some historical events asserted the direct refusal of some Egyptian governors for the

${ }^{36}$ Amer, M. A. (1997). Coins, weights, and measures. Damascus: Ibn Khaldoun Publishing, p. 189.

${ }^{37}$ Al Sawy, A. A. (2001). The coins which were used in Ottoman Egypt.

First edition, Cairo: Arab Civilization Center, p. 95.

${ }^{38}$ Pere, N. (1968). Osmanlianda medeni paralor: Coins of the Ottoman Empire, Istanbul. p. 229.

${ }^{39}$ p. 6.

${ }^{40}$ Pere, N. (1968). Osmanlianda medeni paralor: Coins of the Ottoman Empire, Istanbul, p. 229.

${ }^{41}$ Sultan, J. (n. d.). Coins of the Ottoman Empire and the Turkish Republic: A detailed catalog of the Jem Sultan collection, Vol. 1. U.S.A., California: B. \& R. Publisher, p. 282.

${ }^{42}$ Al Sawy, A. A. (2001). The coins which were used in Ottoman Egypt. First edition, Cairo: Arab Civilization Center, p. 96. 
struck of the former Para multiples, which were mentioned earlier.

As stated by Al-Jabarti, in the events of the year 1119A.H. / 1720 A.D., Egyptian Emirs (Princes), obeyed the official orders of the Ottoman Sultan to mint the Zolota, then the Sultan was forced to accept their desire ${ }^{43}$, thus the situation remains as it has been concerning the monitory trade.

Moreover, again with the same kind of silver coin, in the year 1128A.H. / 1716 A.D., the Sultanate decree came with the order of minting the Zolota, which was also confronted by refusal. Besides, another refusal came in 1135A.H. / 1723A.D. against minting the silver coins based on the prototype of the golden Zingerle $^{44}$.

Also, the year 1129 A.H. /1717 A.D. witnessed another refusal to mint the "Kurus", which was another kind of the Para multiples that equaled 40 Para, and that refusal came as a result of the role that was played by the European Real in the Egyptian trade, which left no excuse to have the necessity to mint a coin with an equal value ${ }^{45}$.

In this regard, it is important to mention that in other periods, Egypt has witnessed the Kurus struck, as in 1186 A.H. / 1772 A.D. Some of the Para multiples were struck in the pieces of five

${ }^{43}$ Al Jabarti, A. A. (2003). Ajae'b al-athaar fe al-tarajem wa al-akhbar. Edited by Abdel Reheem Abdel Rahman. Part One, Cairo: The General Egyptian Book Organization, p. 46.

${ }^{44}$ Al Sawy, A. A. (2001). The coins which were used in Ottoman Egypt.

First edition, Cairo: Arab Civilization Center, p. 232.

${ }^{45}$ Raymond, A. (1999). Artisans et commercants au Caire. Le Caire: Institut Francias d'Archeologie Orientale, p.26. 
and ten Paras ${ }^{46}$, and also the Paras of 20 and forty, which held the Sultan's Tugra ${ }^{47}$.

In fact, this procedure came when Ali Bey al-Kabeer, Egypt's governor during the reign of Sultan Mustafa the Third (11711187 A.H. / 1757-1774 A.D.) attempted to show the Ottoman Sultanate his power and authority in Egypt by minting the Para multiples which was a trend held by the Sultanate only. Thus, he wanted to show the Ottoman Sultan that he is equivalent to him.

In turn, these categories of coins were distinguished by his name mark $^{48}$, along with the year when he was dominant, and held the authority as a governor in 1183 A.H. / 1771 A.D. ${ }^{49}$. Hence, as it is obvious, even when the procedure of minting all the Para multiples was held at a certain time, it was with the concealed intention of showing authority and confrontation.

Even when Samuel Bernard mentioned the struck of some para multiples, he noted that only a very small amount of it was minted, as it did not represent a significant role in the monitory system of Egypt ${ }^{50}$.

In conclusion, in light of what was mentioned in this research, it is clear that studying coins from an analytical perspective assisted in shedding more light on its role, and accordingly in clarifying some political facts concerning the relation between Egypt and the Ottoman Sultanate. That is, the Egyptian

${ }^{46}$ Fahmy, A. (1976). The coins used during the time of Al-Jabarti. Cairo: The General Egyptian Book Organization, p. 574.

${ }^{47}$ Bernard, S. (2002). Description of Egypt. Part 6. Translated by Zuheir alShayeb. Cairo: The General Egyptian Book Organization, p. 74.

${ }^{48}$ Al Jabarti, A. A. (2003). Ajae'b al-athaar fe al-tarajem wa al-akhbar. Edited by Abdel Reheem Abdel Rahman. Cairo: The General Egyptian Book Organization, p. 448.

${ }^{49}$ Mubarak, A .B. (1883). New plans for Egypt and its old and famous states. Part 20, Cairo: Beau Lac Printing House, p. 128.

${ }^{50}$ Bernard, S. (2002). Description of Egypt. Part 6. Translated by Zuheir alShayeb. Cairo: The General Egyptian Book Organization, p. 182. 
governors attempted most of the time to show their limited power by the refusal of minting the Para multiples, and to reflect the rejection to becoming a mere subsidiary state to the Ottoman Sultanate, since many of these governors were Mamluks. Thus, in general, opposition to strictly abide by Ottoman regulations was not only reflected in the refusal of minting Para multiples, but also in minting them on behalf of Aly Bey al-Kabir, for he did so with the intention of power affirmation and confrontation against the Ottomans rather than as a sign of genuine acceptance. 


\section{REFERENCES}

- Al Jabarti, A. A. (2003). Ajae'b al-athaar fe al-tarajem wa al-akhbar. Edited by Abdel Reheem Abdel Rahman. Cairo: The General Egyptian Book Organization.

- Al Sawy, A. A. (2001). The coins which were used in Ottoman Egypt. First edition, Cairo: Arab Civilization Center.

- Amer, M. A. (1997). Coins, weights, and measures. Damascus: Ibn Khaldoun Publishing.

- Arafa, E. M. (2006). The Coins which were used in Egypt during the French Expedition. (M.A. Thesis). Cairo University: Faculty of Archeology, Egypt.

- Bernard, S. (2002). Description of Egypt. Part 6. Translated by Zuheir alShayeb. Cairo: The General Egyptian Book Organization.

- El Nabarawy, R. (2000). The Islamic coins from the beginning of the $6^{\text {th }}$ century till the end of the $9^{\text {th }}$ century A.H. First edition, Cairo: Zahraa alSharq Library.

- Fahmy, A. (1976). The coins used during the time of Al-Jabarti. Cairo: The General Egyptian Book Organization.

- Gibb, H. (1989). Islamic society and the West. Cairo.

- Inalik, H. (1994). Money in the Ottoman Empire: an economic and social history of Ottoman Empire. Cambridge University Press.

- Mahmoud, A. M. (2003). Ottoman coins: Their history and problems. Cairo: Faculty of Arts Library.

- Mansour, A. R. (2008). The Islamic coins and their importance in studying history, archeology, and civilization. First edition, Cairo: Zahraa al-Sharq.

- Mubarak, A .B. (1883). New plans for Egypt and its old and famous states. Part 20, Cairo: Beau Lac Printing House.

- Oghlu, A. A. (1999). The Ottoman state, history, and civilization. Translated by Saleh Saadawy. Part 2. Istanbul: Islamic History, Arts, and Culture Center.

- Pere, N. (1968). Osmanlianda medeni paralor: Coins of the Ottoman Empire, Istanbul.

- Pipes, D. (1983). Mamluk survival in Ottoman Egypt. Journal of Turkish Studies. 
- Pitcher, D. E. (1972). A historical geography of the Ottoman Empire from earliest times to the end of the $16^{\text {th }}$ century. Brill Archive.

- Raymond, A. (1999). Artisans et commercants au Caire. Le Caire: Institut Francias d'Archeologie Orientale.

- Shaw, S. J. (1962). The financial and administrative organization and development of Ottoman Egypt: 1517-1798. Princeton.

- Suleiman, A. A. (1972). History of the Islamic countries and the lexicon of the ruling dynasties, part 2, Egypt: Dar al-Maaref.

- Sultan, J. (n. d.). Coins of the Ottoman Empire and the Turkish Republic: A detailed catalog of the Jem Sultan collection, Vol. 1. U.S.A., California: B. \& R. Publisher. 


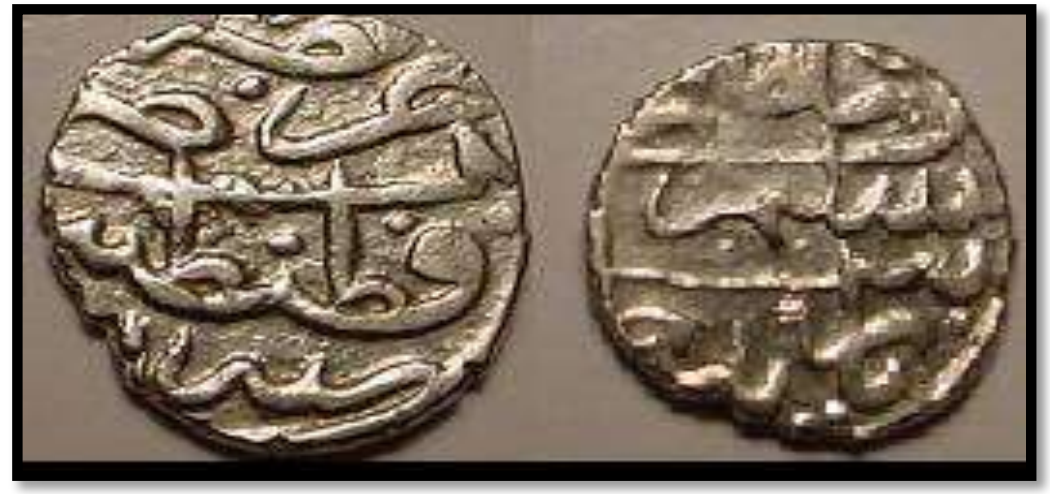

Figure (1): Akce struck in Constantinople under the name of Sultan Selim the firs, on the obverse there is the name of the Sultan with a raising phrase, and on the reverse the mint name and date. www.osmanliparalar.com

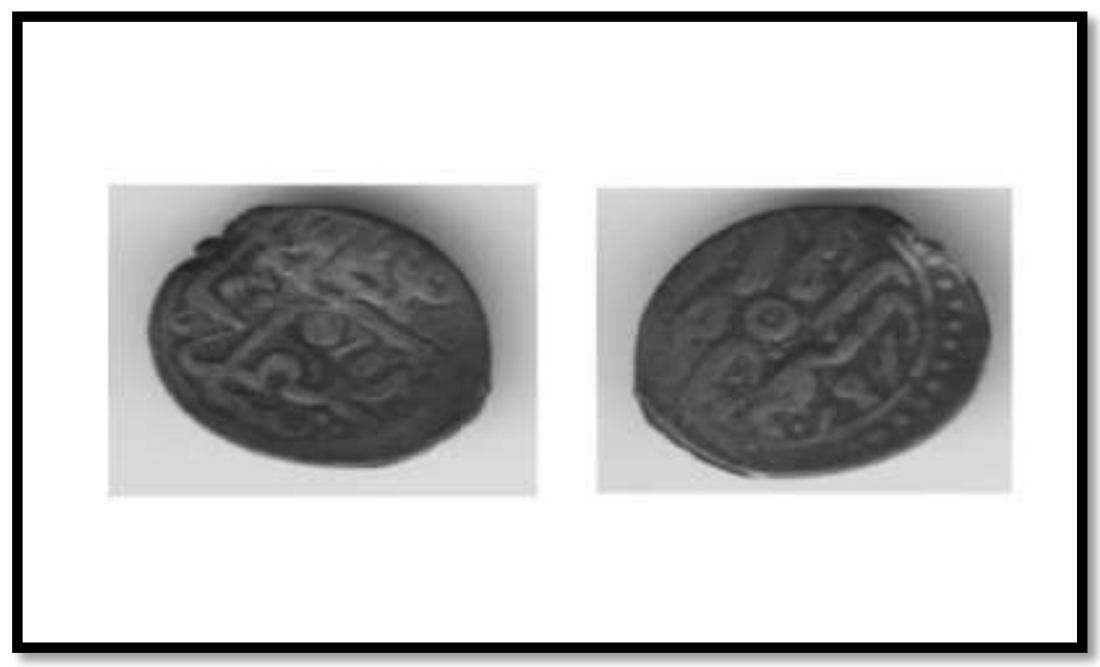

Figure (2): Para struck in Egypt under the name of Sultan Suleiman Bin Selim, with his name and the title "Shah" on the obverse, and on the reverse the mint name and date. Preserved in Tubingen Museum, under num. Df2 $F 2$. 

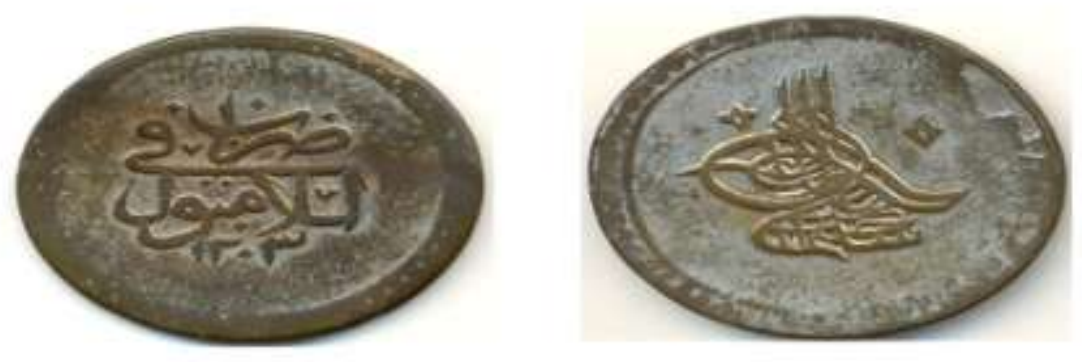

Figure (3): Para struck in Istanbul, under the name of sultan Selim the third, with his Tugrah "monogram", on the obverse, and on the reverse the mint name and date. Preserved in the Islamic Art Museum in Cairo under number 17932/4

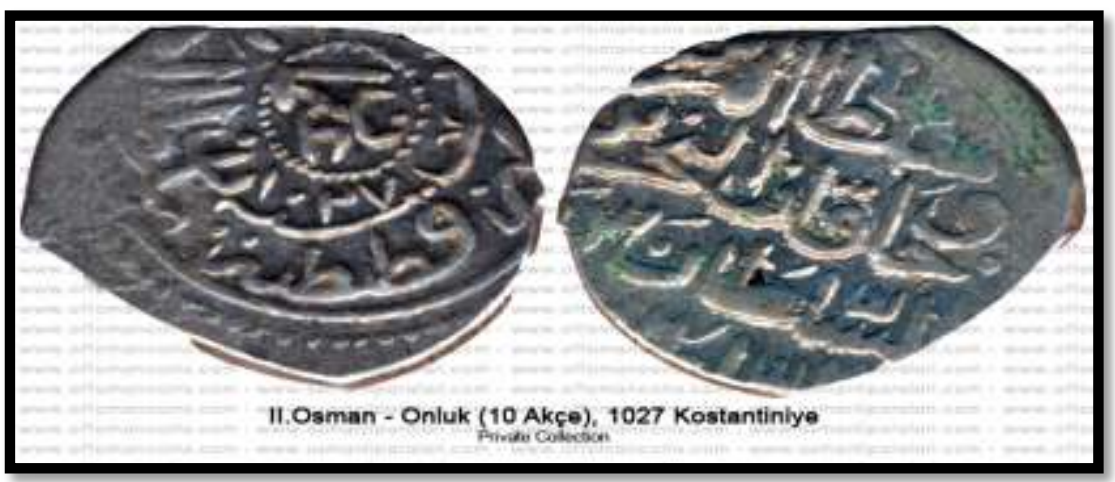

Figure (4): Onluk-10 Para-struck under the name of Sultan Osman the second, on the obverse there is his name along with the mint name and date, and on the reverse there is the famous Ottoman raising phrase: "The ruler of the two continents, the khan of the two seas, the king, son of the king". www.osmanliparalar.com 


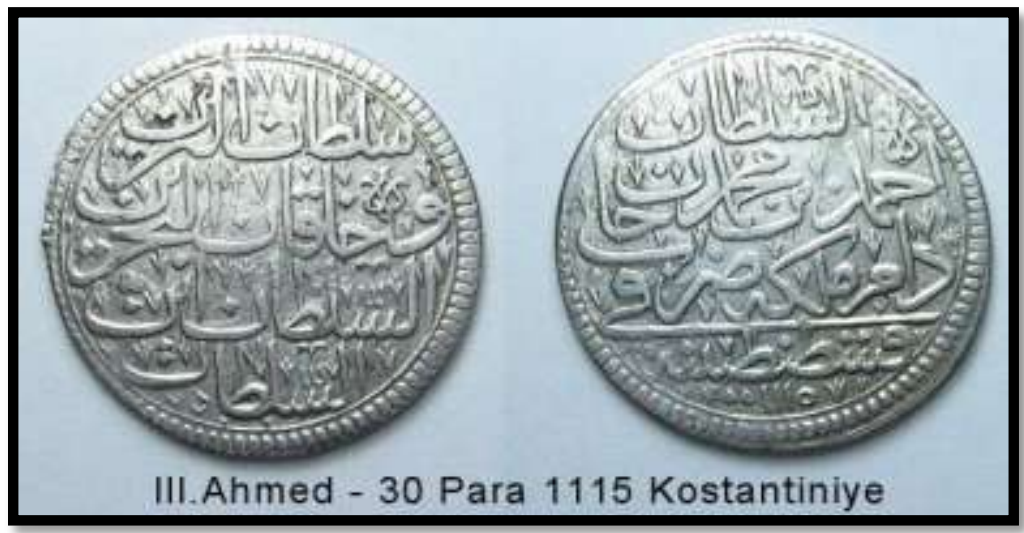

Figure (5): Zolata -30 Para-struck under the name of Sultan Ahmed the third, on the obverse there is the name of the sultan with the mint name and date, and on the reverse there is the famous Ottoman raising phrase: "The ruler of the two continents, the khan of the two seas, the king, and son of the king". Pere, N. (1968)

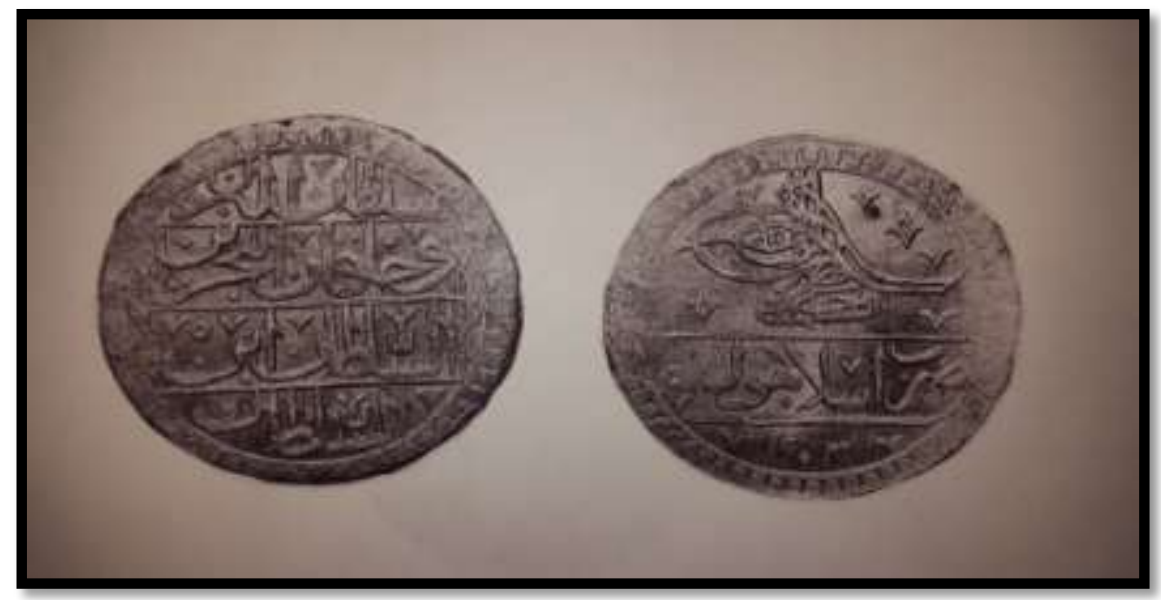

Figure (6): Yuzluk-100 Para-struck under the name of sultan Selim the third, on the obverse there is the Tughrah of the sultan along with the mint name and date, and on the reverse there is the famous Ottoman raising phrase: "The ruler of the two continents, the khan of the two seas, the king, and son of the king”, Sultan, J. (n. d.) 
رفض مصر لضرب مضاعافات البارة العثمانية وما تعكسه

\section{من العلاقة السياسية مع السطنة العثمانية}

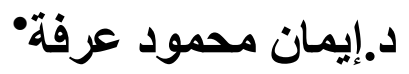

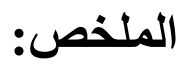

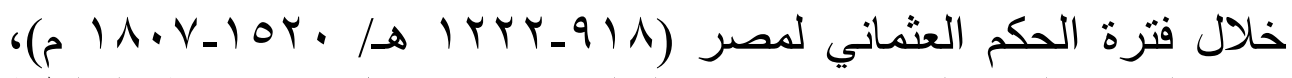

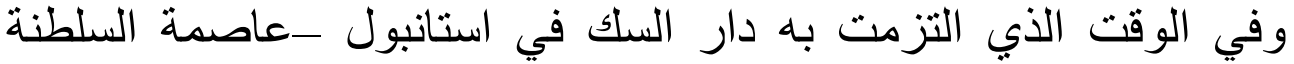

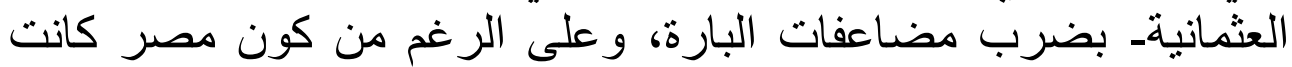

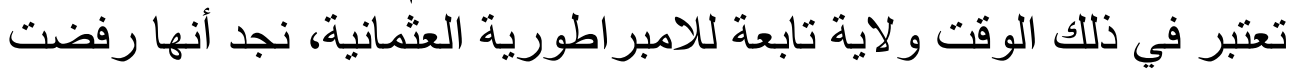

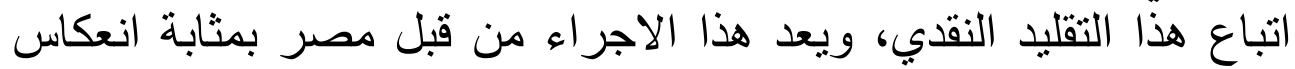

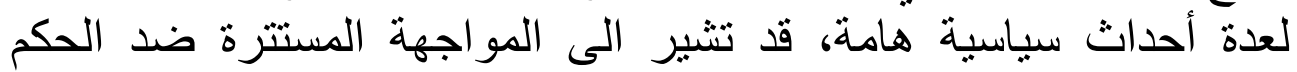

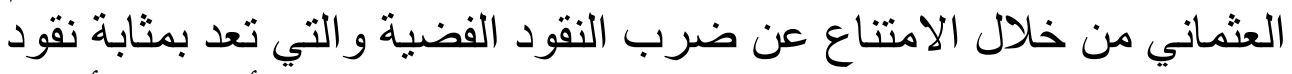

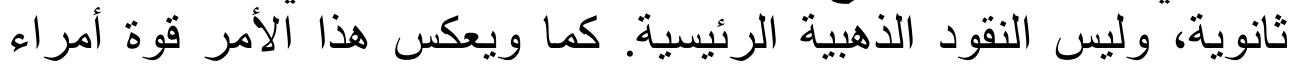

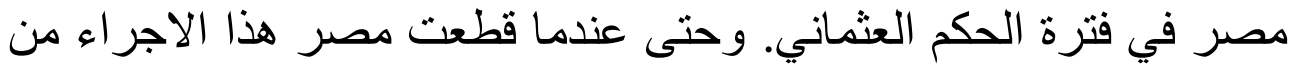

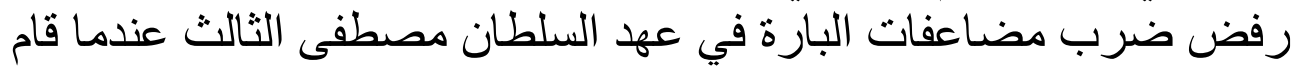

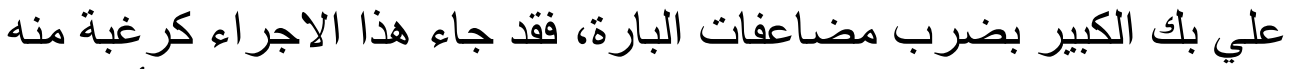

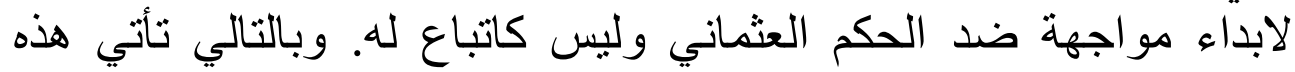

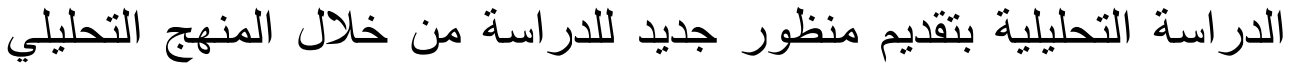

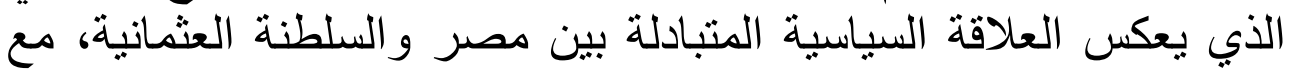

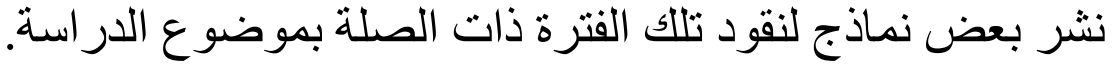

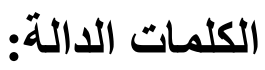
الفترة العثمانية ـ مضاعفات البارة - ضرب ـ العلاقات السياسيةـ مدين 